Canadian University Music Review

Revue de musique des universités canadiennes

\title{
In Doig People's Ears
}

\section{Howard Broomfield}

Numéro 5, 1984

URI : https://id.erudit.org/iderudit/1013934ar

DOI : https://doi.org/10.7202/1013934ar

Aller au sommaire du numéro

\section{Éditeur(s)}

Canadian University Music Society / Société de musique des universités

canadiennes

\section{ISSN}

0710-0353 (imprimé)

2291-2436 (numérique)

Découvrir la revue

\section{Citer cet article}

Broomfield, H. (1984). In Doig People's Ears. Canadian University Music Review / Revue de musique des universités canadiennes, (5), 123-135.

https://doi.org/10.7202/1013934ar

All Rights Reserved (c Canadian University Music Society / Société de musique des universités canadiennes, 1984
Ce document est protégé par la loi sur le droit d'auteur. L’utilisation des services d'Érudit (y compris la reproduction) est assujettie à sa politique d'utilisation que vous pouvez consulter en ligne.

https://apropos.erudit.org/fr/usagers/politique-dutilisation/ 


\title{
IN DOIG PEOPLE'S EARS
}

\author{
Howard Broomfield
}

In Doig People's Ears is a forty-five-minute composition for audio tape and voice. It is a series of soundscapes that are juxtaposed to create a feeling for the history of the Beaver Indian people (Dunne-Za). The work is addressed to the people of the Doig River Reserve, a community near Fort Saint John on the industrial frontier of northeastern British Columbia. "The Doig" has been the locus of a field recording project that was organized by Robin Ridington, an anthropologist at the University of British Columbia, who has known the Beavers since 1964. The rhythms of life at Doig and an imaginative collaboration between some of the members of the community and the research team have generated nearly three hundred hours of recordings that document everyday life situations including hunting, homemaking, storytelling, and music making, as well as ambient sound. ${ }^{1}$

I began working with Dr. Ridington as a field recordist and audio documentarian in 1979. Between 1979 and 1982 we made four trips to Doig which ranged in duration from two weeks to two months. Our research used the participant observation technique of social inquiry. We either camped on a hillside overlooking the village, lived with people in their homes, or travelled with people to traditional camping places. The Dunne-Za were amused at the way we took sounds in the way that most people took pictures. We recorded crying babies, cooking food, and clothes being washed. Men invited us to "tag along" when they went to hunt or work on jobs. We joined women for berry picking and shopping trips. Parents were delighted when their children sang or performed recitations for us. We were taken to taverns and churches. We visited family friends. 
Although we were interested in such cultural products as songs, stories, and the discussion of contemporary issues, we did not seek to buy them. Instead we entered into an emotional and material symbiosis with Dunne-Za who extended themselves toward us. When we had a vehicle we drove people who had no vehicles. When there was good hunting people brought us meat. If someone had trouble with the courts or some other type of bureaucracy we took a position of advocacy. If Indians challenged our presence in social situations someone would speak for us. When we talked through the night about love and death we enlightened each other. When we asked people about their families, backgrounds, and religions they asked us to talk about ours. We gave those parts of ourselves as sacraments to a project of common knowledge and reflection so that both they and we could begin stories in the future, "I knew this person once ...."

The Beavers trusted that we could use the tapes in a way that would be beneficial to their children and to their children's children: so that if there was a time when there was no Doig, a ghost of Doig would continue to speak. When we produced audio productions we sent copies to friends at the Doig and asked that they share them with other people. Sometimes we received requests for copies of particular master tapes.

Our work is innovative within anthropology because it documents the complete range of aural culture and soundscapes. It includes information about a variety of settings from those in which there is little or no human activity through informal conversations to formal events such as interviews and ceremonials. Since the Beavers were until recently concerned with the oral/aural transmission of knowledge and history, our documents of verbal performance styles are especially interesting.

Our sense of global audio documentation has been strongly influenced by R. Murray Schafer's discussion of sound symbolism, acoustic community, and the soundscape as an indicator of social welfare (see Schafer 1977). We hope that our archive will serve as a valuable resource for future generations of Dunne-Za as well as for musicologists, linguists, students of expressive culture, soundscape designers, and others who are interested in analyzing the sounding aspects of culture. As a composer my work is to synthesize the diverse elements that we have collected in order to provoke an understanding of the Dunne-Za. 
In Doig People's Ears is a crafted excerpt from the Dunne-Za Archive. It is like a stained glass window: a mosaic of scenes from everyday life. Each scene is focussed by language that locates it according to time, place, and circumstance. All of the materials were recorded in the field using high quality portable equipment. Editing units were selected according to informal and formal cataloguing procedures. Mixing was accomplished using a ten-band graphic equalizer and a four-channel tape recorder. The rest of this paper is a rendering of something that is heard into something that is read: it is the score of an imaginary soundscape that is to be performed in the mind's ear.

1. A very old man, perhaps the oldest living Beaver Indian, singing close to your ear. Through the effort to maintain his tone you can hear the shape of traditional Beaver chanting: ${ }^{2}$

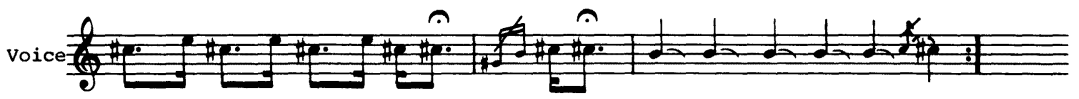

He was born around the time the fur trade was becoming unprofitable and the Dunne-Za were worried about dwindling food supplies and the growing population of white people. His song emerged from an education that taught how to be human in relationship to animals that could be transformed into food and material things. A central feature of that education was going into the bush alone and meeting with the animals. From those meetings he would know a song that he would associate with the power and knowledge to survive.

The song is central to supernatural power. Indeed, the only word in Beaver for the whole complex of supernatural attributes, medicine bundle and behavior taboos is ma-yine, literally "his song." Just as the cries and habits of animals are their language and the essence of their specific identity ... the song is like an animal cry that stands for the identity of a man with his guardian species. The Beavers say that in the vision quest, children learn to talk to animals. This statement is quite literally true in that they learn to use and understand the behavioral and vocal communication of an animal species (Ridington 1968: 91).

2. A small group of people are walking along a hillside above a road and a river. A man in his thirties speculates aloud 
against a counterpoint of automobiles on the road below and footfalls through the bush. He speaks with authority from the past in contemporary Reservation English:

I think we used to be one group, all of us. But after we had a war everybody spread out. Some of them went North, East, and West. States: they're Blackfoot, eh. Some of them Sarci, Carrier, but one time we were all just Beaver... thousand years ago.

I guess long time ago, he said, you know, there were lot of animals. Like lotta moose, and what do you call them, buffalo. We got lot of things, you know, animals. One summer you know, they lost everything. Even all the animals died, you know. Some kind of sickness, he say. Before the white man came. Then some people they head for the hills, too, like mountains. They survive, huh. The one's that live out here kicked the bucket.

The soundscape around him grows thicker with footsteps, birds, insects and the river. He continues to talk about buffaloes, migrations, and a war with the Cree. He says things that he heard from people who taught him how to hunt for food and trap for money. He speaks in a voice that knows construction work, conference rooms, and movie theaters. He speaks in a voice that knows how voices play when they speak beside a fire.

3. An itinerant singer/story teller and three other men playing drums perform "The Sikanni Chief's Song" at a large gathering of people. The song goes back to the late eighteenth century when the fur trade was reaching its peak. A Beaver hunt chief named Makenunatane was called "The Swan Chief," a reference to the animal that he encountered on his vision quest. Metis voyageurs referred to him in French as "Cygne" (Swan). Anglophone traders mispronounced his name as the Dunne-Za speak it today (Ridington 1983).

Makenunatane is known as the first prophet or Dreamer of what the Dunne-Za call "Indian Religion." Legend has it that he went to sleep one day and that he slept until the next. People kept watch over him and knew he was alive because his throat kept moving. People said that he had gone to heaven. When he awoke he sang his song to the people and lectured them on what was right and what was wrong.

From his contact with the Metis, Makenunatane learned about the white man's tools, technologies, and ideas. In his dreams that knowledge combined with knowledge about his 
own culture and he predicted how it would be when the white man appeared. The process was similar to the way that he, as a hunt chief, had predicted the movements of animals.

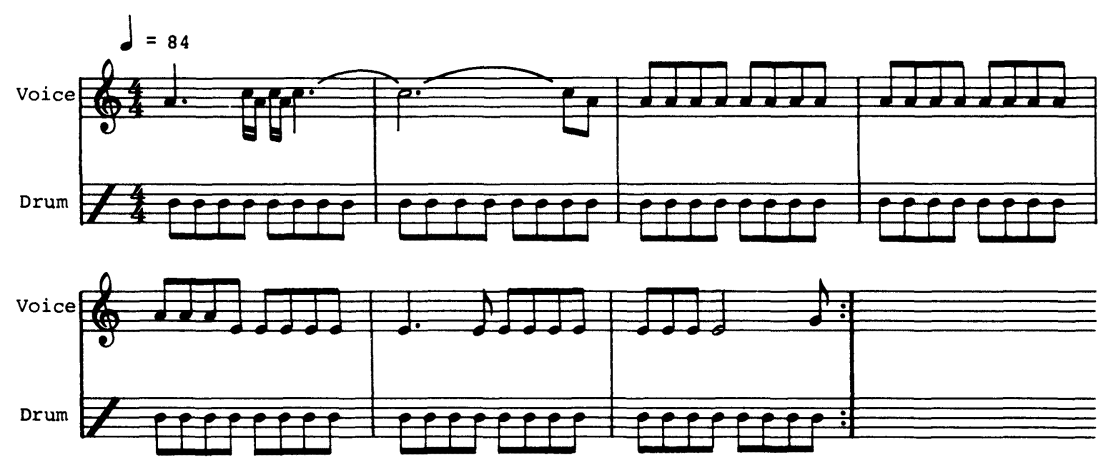

4. A middle-aged man with his ear to the past describes the relationship between Indian Religion and Christianity:

Since I know we've got a priest, you know. White man. He talk Beaver, Slavey, and all kinds of language. He can write it too. Before the priest come, you know, then I think they know about God. Maybe three hundred years ago or four hundred years ago. They know from these medicine men, quite a few of them you know; their songs still today. They dream about heaven, about Jesus, like that. And these medicine men, long time ago before the white man came, any time of year, when they sleep, eh, they get new songs. That's the time they make pow wow for one week. They celebrating for that new song. They take their dreams to heaven, then they make songs, and they tell what's gonna happen. Not anybody medicine man, gotta be good man.

The Catholic priests who converted the Beavers in the middle nineteenth century took their authority from knowledge that was written in their books. The Dreamers took their authority from the personal experience of their vision quest, their conduct in the community, and their ability to hear songs in their dreams.

A soundscape of footsteps on frozen snow surrounds the man's voice and continues into the next setting.

5. Between November and March there are heavy snows. The listener must speculate on the types of snow that could be named: snow that's good for tracking animals, snow that's good for dog teams, snow that makes good water, snow that's good 
for snowshoes, snow with sun that makes a man blind. Imagine how the ear hears in a place when it is usually dusk and night, and very cold. Around a fire talking, singing, and dancing. Living very close to others; hearing their breath, their movements and their voices. Before the white man came. Hearing things being made: stone working against bone and stone (obsidian, basalt, sandstone, quartzite, copper, slate, and flint); a bone knife cutting animal sinew. In the cold and dark. Hearing dogs bark nearby and then a wolf howling across the river so that someone gets a drum and starts to play (wood hits stretched hide and vibrates porcupine quills) and other people start to play and soon the dogs and the wolf are no longer audible.

Footsteps continue in the snow. There is whistling and the footsteps stop. Then there's a gun shot. A Dunne-Za hunter is combining traditional artifice (whistling to stun the animal) and an innovative artifact (the rifle) to transform a rabbit into food.

The footsteps continue and recede into the background so that voices speaking Cree and the sound of metal clanging against metal emerge into the foreground. Throughout the eighteenth century the fur trade was firmly established. It brought artifacts with new sounds and people with new languages and musics. Gunpowder was like thunder or earth tremors. Iron pots had a hard ring. Steel traps snapped like brutal jaws. Alcohol made people talk funny. Footsteps in the snow continue.

6. The fur trade not only brought new artifacts and ideas to the Dunne-Za, it also caused a drain on their resources. Animal resources were overhunted and commercial wars brought hardship to the people. The middle-aged man with his ear to the past talks about the fur traders' reliance on the Indians. The soundscape surrounding his voice transforms from footfalls on hard snow into drumming and singing.

1894 I think, something like that. That's what old Aku told me, including too, my Grandma. That time you know, just where the Beatton and Peace River run together, that's where Hudson's Bay used to live. Now Hudson's Bay they got lotta groceries and everything now, eh. Clothes and everything like that. But that time you know, that's what I hear, Hudson's Bay bring only them gun and the powder. Powder for killing moose. Hudson's Bay used to live on the Indians. He just bring the powder, powder and gun. And what's 
Hudson's Bay got, just got the flour, eh. One cup maybe for the wife and the husband, eh.

The drumming stops abruptly as a baby cries.

7. Philip Godsell, a Hudson's Bay Company trader, offers an earwitness account of the Dunne-Za camped near the trading post at Fort Saint John in 1912:

Nowhere in the Dominion of Canada could a more barbarous and primitive scene be witnessed than the large village of smoke-stained Indian teepees through which we wended our way. The unwhipped Beavers stared at us with insolent and unfriendly looks as we rode between the lodges. They were untamed Indians who still retained their pride of race and looked contemptuously upon the white men as being a decidedly inferior people... (Godsell 1946: 123).

While he is speaking the soundscape around him fills with drumming and cheering.

At the time I was thrilled by the vibrant throbbing of the drums, the quavering and eerie medicine song of the man far up on the hill, and the loud A-ha-a! A-ha-a! A-ha-a-of the gamblers as they played their ancient game, La halle; staking clothes, horses and, at one time, even their wives upon the outcome (ibid.: 124).

8. The gaming soundscape continues:

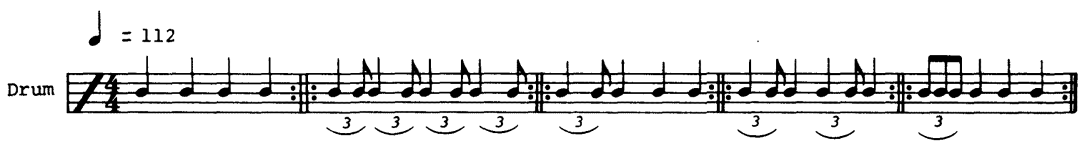

9. The very old man who was born before the turn of the century speaks alone. His style of language is so old that contemporary Beaver speakers can hardly understand him. He sounds as though he is reciting a story that he knows very well. A white man raconteur begins talking simultaneously in an "Old Timer" style of English that reflects the contact culture of the 1920s. The duet emphasizes the musical qualities of their voices. The white man's memory of his first contact with the Dunne-Za is, like Godsell's, filled with the sound of drums.

That whole valley down there below Clark's was filled full of teepees and there must have been about a hundred head of horses and it was in midsummer and it had been a very 
productive summer and the horses were fat and shiny. And after they built their campfires down there and started playing their drums, in 1929 which is fifty years ago, it done somethin' to me that I shall never forget... with kinda mixed feelings. And we stayed up there at the top of the hill and grazed our horses and looked down into the valley and watched the campfires and seen them dancing around the fires. And that was my first really big experience with the Indians. They called it a tea dance.

As he talks music from a tea dance complements his voice.

10. Music from the dance continues. When its thunder becomes hushed horsebells are audible.

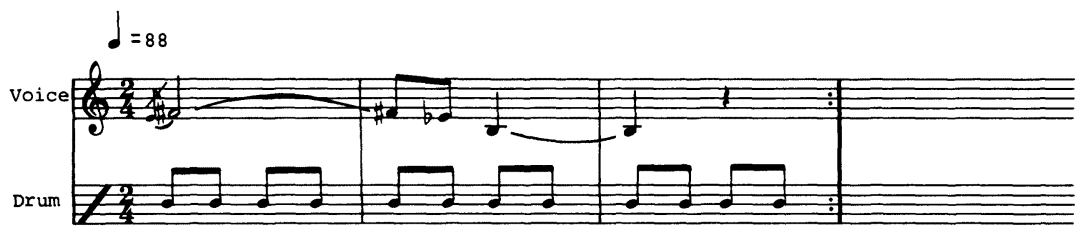

11. The itinerant Dunne-Za storyteller returns speaking in a mixture of Beaver and 1920s-style Reservation English. His language is counterpointed by the squeaky door of a contemporary reserve house and a modern automobile engine. His story is set in 1931 when Dunne-Za trapping and land use was upset by trapper/settlers who were trying to escape hard times in Southern Canada. Some Indians believed that white men had stolen their animals and they sought to regain their wealth by stealing the furs that had been made from the animals. The sound of footsteps transforms into the sounds heard near a river and then into the sound of a fire. Although the Indians moved easily through the bush they were chased by police with gasolinepowered boats. When they heard the police coming they burned the furs and escaped to Fort Saint John. They were apprehended when a friend was trying to spirit them off to the States by automobile. Although some of the details of the story might be questionable it is clear that in the 1930s the Beavers learned the sound of the internal combustion engine.

12. A Cree fiddler and a guitarist from Doig play a dance tune that is characteristic of the music that white men brought into the area in the 1930s and 1940s. Few Cree in the area can perform their ancestral music, but many of them have become 
masters of country and western musical styles. The Beavers, on the other hand, have maintained their traditional music as well as performing an idiosyncratic type of country and western music.

13. While the music is playing a white woman starts talking about the time that she and her husband first came into the country to work on the construction of the Alaska Highway in 1942. Simultaneously an Indian woman sings a traditional song that was dreamed by her father around the same time.

My husband was what was known as a catskinner. They had to have operators for these big machines to build the road -they were big machines then, but pretty small machines by our eyes now-they were pretty big machines coming into a country where people had only been used to horses and it was quite a thing for the people to see the construction and how fast they moved.

The white woman continues talking about the beautiful moosehide jackets that Indian women made and decorated with beads to sell to the construction workers. The glass beads and treadle sewing machines with cotton thread that they used replaced the porcupine quills, bird quills, awls, and babiche that were used traditionally. Although the sound of preparing the hides was centuries old, the sound of transforming the hide into clothing was quite modern.

As she is finishing her talk the Indian woman stops singing and the noise of a large machine begins.

14. The machine clatters on relentlessly until it is given shape by the percussion of logs falling to the drone of a chain saw and the voice of the man in his thirties who is talking from the past into the future:

First time they said they seen cats, eh, boy they were surprised. I guess they went to follow the cats going into the bush. Some old people they remember somebody told them they gonna make a bridge at Peace River. They just laughed. They wouldn't do that, they said, it's too wide. They gotta have long posts, big trees.

But this guy told them-Hudson's Bay Manager, Beattonhe told them, they gonna build a bridge here. Fort Saint John will be big town. But they just laugh. They should see it now!

15. Fragments of three conversations define developments through the fifties and sixties. An old man speaking English in 
the Indian style of the thirties talks about the alienation of land for oil exploration. A woman who was born in the thirties speaks meilifluously of how she learned to speak and write English while working as a housekeeper for the first school teacher's family. The old man's daughter remembers thoughtfully the time when a Department of Indian Affairs agent flew in with a helicopter to tell the people to choose a place where a permanent school and village would be built.

16. The mellifluous woman fades into the background and the white woman returns to talk about coming back to the area in the 1960s when the oil construction was booming. The old man's voice is sounding darkly at the horizon of audibility. When she talks about buying land for two dollars an acre he crosses the threshold to intone:

Something big business, I think

Something boss, see

Been workin' here long time.

She tells how she and her husband invited the Indians to camp in their traditional place after they had bought the land and and how they felt about the occasional visitors:

We didn't mind them coming.

They never harmed anything, right

or anybody

And we didn't need that land.

Beneath her voice the ceaseless crashing of an oil rig surrounds traditional music. The woman talks about seeing places where the Indians had worn the grass off the ground by dancing. The exchange between the music and the noise continues with the music dominating.
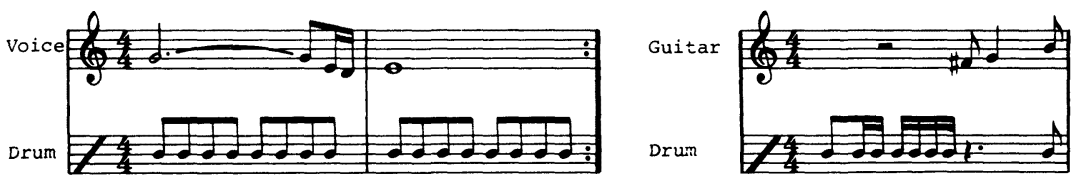

17. The fanfare from Message Time contrasts boldly with the hypnotic music of the Dreamers' Dance. CKNL, th voice of Fort Saint John, gives away fifteen minutes each day of its otherwise commercial airtime, for personal and community messages. Message Time is the only medium for communication 
at a distance for many rural people who, like the people at Doig, do not have regular telephone service. The station came on the air in 1962, one year after the permanent village, complete with school and church had been established at Doig.

As a result of Message Time it is possible for anyone who can get to a phone and speak English to send a message to everyone who has a radio. A previously diffuse network of meeting places is superceded by a central source of information that demands punctuality and possession of a specific artifact.

The church bell hardly rings at Doig, but it rings on the tape to introduce the middle-aged man with an ear to the past and his story of the last wagon trip to Alberta:

After the school out, you know, we all move out hunt moose, make some dry meat, like that summer camping. We go right through Goodlow and through to Alberta. We used to go with wagon. Everybody's got wagon and pack horses and saddle horses. Sometimes sixteen wagons. All the family and kids they stay in the wagons. 'bout maybe sixty people. Last time we went to Alberta is 1966. In 1967 we start farming: we start raising cows. Soon as we start getting cattle most of them stay in here look after the cattle. Some of us go out for two months north of Goodlow to try to hunt moose, do stuff like that, but now with cars and trucks.

While he is talking the white woman tells how she stopped seeing the Indians come through with their wagons, but how she sometimes saw them hunting or picking berries on horseback.

The texture of cattle lowing and children hollering them into a herd moves from the background to the foreground while they are speaking.

18. The herding scene maintains the acoustic foreground. Then it's interrupted by rifle shots. An itinerant laborer, a white man in his late forties who was offered hospitality by the Beavers, explains the situation:

These people aren't gardeners,

these people are meat eaters.

You can see it in the way they don't eat beef.

They'll keep it and sell it.

That's money.

For meat then, they've got the moose and deer

and all this comes out of the woods.

So that they make money on the cattle

to buy shells

to take meat out of the woods. 
A young boy starts speaking before the man is finished. He says that his school is supposed to be an Indian School, but that white kids now greatly outnumber Indian kids.

The boy's voice becomes quieter and the white woman tries to remember the not too distant time in the past when herds of wild horses and Indians lived on the open prairie. She expresses regret that the Indians have been pushed off of most of their land.

The boy's voice rises again speaking of his plans for the future: to be a lawyer, maybe drive truck in his spare time; to earn lots of money, have a home and lots of vehicles. He might drink once in a while and sing in local nightclubs.

A Christian hymn in Beaver parallels his voice. The white woman expresses admiration for a missionary family who lived with the Beavers and taught them a lot about Western technology -especially literacy and mechanics.

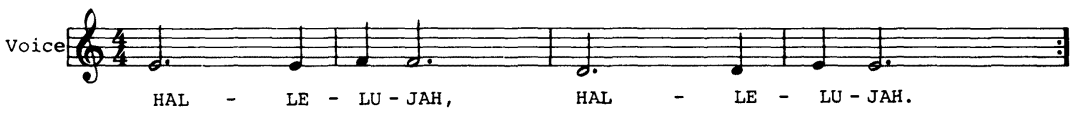

The boy says that unlike some other boys he does not want to drop out of school to work on reserve projects because "there's a world to be found out." While the worshippers continue to sing he recites the lines of a country song, "Won't you sing me back home with a song my momma sang. Let my poor memory hang around." He concludes "There isn't going to be Doig here forever."

19. When the boy is completing his complex expression of doubt and hope the very old man speaks softly. His words have a questioning resonance. He pauses, awaits a reply, and weeps. Chimes sound as the old man's voice becomes strong and singular. The ringing fades slowly, begging the question: Who will the Dunne-Za know themselves to become?*

* In Doig Peoples Ears is available as a stereo audio casette and as a video tape which is informed by slides and historical photos. Information regarding rental or purchase ran be obtained by writing:

The Dunne-Za Archive

c/o Professor Robin Ridington

Department of Anthropology

University of British Columbia

Vancouver, B.C.

Canada V6T 1W5 


\section{NOTES}

1. Financial and material support for the collection of the Dunne-Za Archive has been granted by The National Museum of Man (Canadian Ethnology Service) and The University of British Columbia (Department of Anthropology).

The field recordists were Morgan Ashbridge, Howard Broomfield, Jillian Ridington, and Robin Ridington. Recordings for In Doig People's Ears were by Howard Broomfield and Robin Ridington.

2. Free renderings of melodic and rhythmic forms were done by composer/flutist Don Druick.

\section{REFERENCES}

The Athapaskans: Strangers of the North. Ottawa: National Museums of Canada, 1974.

BRODY, $\mathrm{H}$.

1981: Maps and Dreams: Indians of the British Columbia Frontier. Vancouver: Douglas and McIntyre.

GODSELL, P.H.

1946: "The Untamed Beaver Indians," in Arctic Trader: An Account of Twenty Years with the Hudson's Bay Company.

LILLOS, B. 6th edition revised. Toronto: MacMillan, 123-33.

1977: "Beaver Indian Music: A Structural Analysis." Master's thesis, University of British Columbia.

RIDINGTON, R.

1968: "The Environmental Context of Beaver Indian Behavior." Ph.D. dissertation, Harvard University.

1978a: "Metaphor and Meaning: Healing in Dunne-Za Music and Dance," The Western Canadian Journal of Anthropology, VIII/2, 3, 4, 9-17.

1978b: Swan People: A Study of the Dunne-Za Prophet Dance. Mercury Series No. 38. Ottawa: National Museum of Man.

1983: "From Hunt Chief to Prophet: Beaver Indian Dreamers and Christianity," paper presented to the American Anthropological Association, Chicago, November 1983; Arctic Anthropology (1984), in press.

SCHAFER, R.M.

1977: The Tuning of the World. New York: Knopf. 